\title{
IMAGE OF THE UNIVERSITY FACULTY IN THE VIEW OF STUDENT TEACHERS
}

\author{
Baiba Kalı̧̧ \\ Sanita Baranova \\ University of Latvia
}

\begin{abstract}
In the article „Image of the University Faculty in the View of Student Teachers", the methods of survey and analysis of performance results are used to explore the image of university faculty in the experience of students of teacher education and pedagogics. An illustrative example is one of the key tools of education in pedagogics. It is significant to investigate the image of university faculty in teacher education because the university teacher also serves as a model of the professional pedagogical performance for student teachers in teacher education. The article highlights the visual image of the university teacher and their most typical personality traits that might have impacts on the future professional performance of student teachers.
\end{abstract}

Keywords: image, university faculty, student teachers, model.

\section{Introduction}

Individuals representing various professions are to comply with certain formal requirements with regard to their professional competence. However, there are also informal requirements for other personal qualities in the professional performance, such as behaviour in public, personal traits, dressing style, which any specialist in the particular profession is expected to possess. The society has certain stereotypes in its perception of professions, and such perceptions build the image of professions or positions. Intentional creation of personal image in the society is highly significant nowadays. It is of particularly high importance in the professions involving interactions with other people. (Lejniece, 2005) Therefore, the outer image of a teacher is essential regardless of the level of education in which they work, and this equally applies to each individual and the profession as a group in general. Furthermore, the outer image cannot be isolated from the inner world of the individual.

Studying the professional performance and competence of the teacher is comparatively traditional in pedagogical research. The image of the university faculty has not been studied in Latvia, and the stimulus for such research was the research into the image of the teacher. In Latvia, the image of the teacher has been studied by the scientists Iveta Ķestere and Baiba Kalı̧e (2010, 2014), who have identified in their research studies that the image of the teacher is a „pedagogical tool”. It is twice as significant to investigate the image of the university faculty in teacher education because a university teacher also serves as a model of the professional pedagogical performance for student teachers in 
teacher education. In teacher education, a university teacher not only teaches the content, but also demonstrates how to teach.

In their image, the university teacher should intentionally promote and highlight the qualities which facilitate students' studying, awareness of educational needs, attitude towards learning, and the chosen professional performance.

The aim of this research study was to find out the image of the university faculty as perceived by student teachers, because the university teachers might use their own example to influence the opinions, points of view, action, behaviour, and style of students to support the awareness of their professional identity among student teachers. To achieve the aim set for the research, the selected research methods included a survey and performance analysis.

\section{Overview of Previous Research}

Image is a widespread category in the area of etiquette, and, in its narrowest meaning, it „describes a purposefully created view of people or things. In the broadest meaning of the word, every individual has their image (including teams, organisations, professions, etc.). It is the way the individual is perceived by other members of the society." (Lejniece, 2005, 31) Image is a perception that implies the inner and outer personal characteristics and social roles.

Psychologists and etiquette experts believe that the outer image of an individual (appearance, language, voice tone, facial expressions, gestures) shape the initial positive or negative perception of the personality. It has been calculated mathematically that the clothing and body language represent $55 \%$ of the first impression about the individual, $38 \%$ of the impression is the verbal language, and the role of the content of what is being said is just 7\% (Kestere, 2007).

The clothing plays a significant role in the formation of the attitude towards the individual because the manner is as important as the content. The clothing is socially and historically pre-determined (Weber \& Mitchell, 1995). In her analysis of the ethical aspects in the work of a pedagogue, Z. Lejniece has also indicated that clothing plays a significant role in the development of the image of the pedagogue. The clothing is a significant source of information in the communication process. It is a personality-characterising special sign which contains information about the gender, age, social status, profession, temperament, and other characteristics, shapes the trend with regard to the evaluation of the individual. ,creates a view of the person and describes their readiness for certain action. (..) describes the formation of the self-image of the person, skills of demonstrating it, and the degree of its development." (Lejniece, 2005, 31-32). 
Significant components in the image of the faculty are well-trained voice, clear speech, and adequate body language. All these aspects of a personality are significant mediators in the performance of the university teacher, which is the basis of successful cooperation with the students. At the same time, these communication abilities can always be purposefully improved in the performance of the university teacher. Sources in tertiary pedagogics acknowledge that mutual kindness, respect, demonstration of attentiveness, and honesty should be ensured in the initial university teacher to student communication in particular. Students, for example, highly appreciate it if during the first meeting time is devoted to becoming acquainted with them and their experience. Only by knowing their students the university teacher will be able to organise an exciting, intensive, and student-centred process of studies (Böss-Ostendorf \& Senft, 2010).

The image of the university faculty has been described in literature at various stages of the development of academic positions. For example, the image of a professor in a medieval university is not easy to reproduce today due to a shortage of autobiographical writings. However, it can be seen that the professor had a standing in the community and was recognised by the colleagues and the church (Verger, 1993; Vandermeersch, 1996). The image of the typical medieval professor is largely created by drawings and paintings where the professor is shown as standing in the rostrum while giving a lecture, and, moreover, is depicted as an elderly man.

In late $60 \mathrm{~s}$ of the $20^{\text {th }}$ century, student protests against the obsolete teaching style of the professors took place in several West-European states. The symbol used at that time for the negative image of the university faculty was a professor standing in the rostrum and delivering a lecture. In their protest campaigns, the students' demand that such professors should be dismissed from their departments was used as a slogan. In Germany, for example, this student movement, accompanied by demand for democracy and emancipation, was the beginning of the development of didactics which nowadays still influences the demands for the professional development of the university faculty in the area of pedagogical performance.

At the end of 2014, the Latvian Television demonstrated the Danish sitcom „My Sister's Children” („Min søsters børn”) where a brother of a mother who has a large family was a respected university professor in children's psychology, but it turned out in the practical upbringing of the sister's children that not all theoretical assumptions regarding the development and education of children are true and can be applied. The image of this professor in the film demonstrates a frequently existing assumption in the society that professors are explicit theoreticians, but lack skill in dealing with everyday problems. Another typical point of view in the discussion about the image of the contemporary university teacher is that not all outstanding scientists can be good teachers. 
In early $90 \mathrm{~s}$ of the $20^{\text {th }}$ century, university teachers of 13 countries from all around the world participated in a Carnegie Foundation survey aimed at finding out the professional image (Berufsbild in German) of the university faculty and the professional reality in an international comparison. The common characteristics are high levels of independence in the professional performance (the so-called academic freedom); the tasks to be performed are very complex (joining of scientific and pedagogical performance). The academic and scientific titles, and the academic tradition also play a significant role. Nevertheless, differences have been highlighted between the university teachers working in universities and those working in vocational colleges, for example (Enders \& Teichler, 1995). The common finding in the research studies about university teachers in various epochs is that the academic staff is a largely heterogenous professional group. Nevertheless, the university faculty is believed to be the key precondition for a successful (quality) study process.

In the past the university professor was an elderly person with extensive experience, but nowadays they have become younger (often younger and less experienced than the students sitting in the auditorium). The researchers of Teacher Educator also point out that teacher's profession is undergoing rapid contextual changes. The university teachers working in teacher education must tackle new challenges.

The methodological literature in university pedagogy describes the university teacher as a model (Vorbild in German) and the importance of a model in the professional performance of the younger faculty. It is emphasised that the self-perception of university teachers largely depends on what pedagogues have been teaching them previously. Moreover, one may speak about both positive and negative models (i.e., what the university teacher should not be). It is acknowledged that the model most typically has subconscious influences. The German researchers (Böss-Ostendorf \& Senft, 2010) indicate that the participants of university faculty professional development seminars often find it challenging to answer the questions: What is your model pedagogue? What personal qualities made them a model? University teachers sometimes name their school teachers and not their university faculty. Furthermore, the characterisations may differ largely, and even contradict. For example, a model may be and elderly or a younger person, more reserved or dynamic, one who uses interactive teaching methods, or one who is able to use the „conventional" methods to arouse interest and has helped the students to achieve their learning results. The key common characteristics in the model university teacher are the attitude that is based on the interest in the development of the student, support, and understanding, in conjunction with very good professional competence in the respective field.

The image of the university teacher is also characterised by the requirements for their competence and its characterisation. Research studies also discuss the image of the teacher linking it to the professional competence of the 
teacher (Kestere, 2005). In the context of this research study, the image of the university teacher is the view existing in the imagination of the students, a generalised depiction of the reality, an ideal. „Ideal - a view of a model for human behaviour and mutual attitudes. The subjective ideal depends on the upbringing, the environment, and the personal life experience. (..) Ideals are the perceptions in a particular community, group of people, or in an individual regarding the model in the process of the development of attitudes." (Špona, 2004, 67). A. Špona has also pointed out that ideals facilitate life-long formation of attitudes towards other people and the individuals themselves. „The life offers an endless diversity of situations to children, young people, and adults of today. Everyone needs more or less stable reference points. One of such reference points is ideals. The aim of upbringing is an ideal perception of the personality we would like to see. Publicly recognised models become ideals in the practice of upbringing, and they fall within customs, standards. Individuals internally acknowledge the ideal as significant for them." (Špona, 2004, 68). Ch. Reitzer (2014) also acknowledges that only a university teacher who meets the functions of a model can convincingly facilitate further development of their students and colleagues, by therefore being like a signpost which not only shows the direction, but also encourages, facilitates motivation, and inspires. In the context of research into the image of the university teacher, the following question becomes topical: What reference point the image of the university teacher is in the view of student teachers?

An example is a paragon, model (example of upbringing, example of a teacher, being an example for others), whereas a model is ,an example of how to perform similar activities; what one wishes to emulate, an example (in action or performance)" (Skujina et al., 2000, 118). In pedagogics, the model is the most influential tool of education. The university teacher has sufficiently large influence on their students. The style of teaching in a university reflects the conviction of the university faculty and the system of views with regard to the aims and objectives of education, and this theoretical basis determines the routine study process. The values, points of view, wishes, manner of behaviour, and even the outer appearance of the university faculty are transmitted to students and may influence their further professional motivation and performance. Thus, the personal example of the university teacher may influence student teachers' life performance, because the study process develops their understanding of both learning and teaching, and also determine their awareness of what an ,efficient" teacher is in their opinion.

It is said in the book „Becoming a Teacher Educator. Theory and Practice for Teacher Educators" by authors from the Association of Teacher Education in Europe (ATEE) (Swennen \& van der Klink, 2009) that „teacher educators” include all those who work full-time or part-time in pre-service and in-service teacher education. Teacher educators must be academics and highly skilled practitioners at the same time. Many university teachers are primary school or 
school teachers when they become teacher educators, or they develop the career of a teacher and their career as university teachers simultaneously. It is essential for a university teacher in teacher education in a university to be a researcher as well.

The researcher of adult education Jörg Knoll has used the idea of H. Altmann 'Teachers teach as they were taught, not as they were taught to teach' (Altmann in Knoll, 1998, 17) to justify that the personality of the university teacher is like a tool and a model. It is emphasised in the literature on pedagogy that the university teacher should be aware that the students learn not only what the university teacher tells (the content), but also the way the university teacher offers, structures, reflects, and interprets this content. Thus, the future professionals also acquire the type of thinking, models of behaviour, and the professional culture. (Knoll, 1998; Böss-Ostendorf \& Senft, 2010) Ch. Reitzer (2014) has pointed to the principle that a role model sometimes tells more than a thousand words. She describes three types of role models. The first one is the university teacher as a role model, because the university teacher always has the function of being an example. With their experience and mentioned examples, the university teachers encourage the students to express their opinions and compare them with the reasoning of the university teachers. It is thus shown that reflection is significant in the identification of a model. Models also include peers whom students initially find it easier to identify themselves with. Examples of role models can also be offered in video materials. J. Knoll points out that, along with the explicit dimension of teaching in a university, there is the implicit dimension of teaching in a university, i.e., the way the university teacher treats their students. A special role in the unity of these two dimensions is played by the study areas in which the students are prepared for work with people. Behaviour and action act silently, unnoticed, along with the content of the studies (Knoll, 1998). The influence of this invisible potential on the personalities of student teachers, their professional development, and performance has not been researched in Latvia.

\section{The Research Methodology and Research Base}

Considering the theoretical rationale of the researched problem, the qualitative design was chosen for the study. The aim of the qualitative study includes gaining more in-depth understanding of the image of university teachers in the view of students based on comprehension of versatile, socially constructed realities and looking at them within the context of teacher education.

The research sample consists of 85 students (future teachers) of the Faculty of Education, Psychology, and Art of the University of Latvia.

The most suitable method selected for the acquisition of the practical results of this research study was a modified survey consisting of a single question. Although the data obtained during the survey cannot be attributed to 
entire Latvia (because they are based on the responses received from 85 respondents), they build an understanding of the image the university faculty have in the view of student teachers. The research sample was chosen randomly, i.e., it consisted of students with various levels of higher education (students of Level 1 vocational study programmes, Bachelor and Master degree study programmes) who were willing to take part in the survey. The second method used by $7 \%$ of all respondents was analysis of the performance results, as those who preferred to do so were allowed to draw the university faculty.

Investigation of the image or portrait of a professional group based on the data obtained in a survey, on the one hand, allows to get the ,arithmetic mean”. However, due to prevalence of qualitative data in the investigation of such an issue, one cannot speak about any mathematical calculations, but rather about a descriptive characterisation.

\section{Data Analysis Methods and Results}

One may hypothetically assume that the image of the university faculty influences not only the students' understanding of the duties of the academic staff, but also the pedagogical performance as such, responsibility, and awareness of the professional identity of student teachers.

In the questionnaire, the students had to provide a free description of the typical university faculty in their opinion (appearance, age, gender, clothing, footwear, accessories, voice, and other characterising features which seem significant).

What is the image of the university faculty in the view of student teachers then? The historians of pedagogics M. Vick (Vick, 2000) and A. Novoa (Nóvoa, 2000) suggest that the following should be considered when analysing the image of the teacher: gender, age, clothing, accessories, hair style, voice tone (how clearly, with what modulation, how loud, and how calmly the teacher speaks), facial expressions, body language, gestures (smile, eye contact), location in the classroom (how much time during the lesson the teacher spends sitting, how close they are to the learners), manners.

Since the university faculty perform many of the functions the teacher performs, the analysis of the image of university teachers was based on the above criteria, which were adapted to the environment in the institution of higher education. Using content analysis, the data were analysed by the authors of the study and the article. The content analysis included coding of information and grouping of the statements provided in the questionnaires by the categories describing the image of university teachers.

Gender. The respondents often mention university teachers of both genders, but females still prevail in the drawings. It is mentioned in several (9) questionnaires that the gender of the university teachers depends on the field they work in (predominantly males in the exact sciences and mostly females in 
the humanities and social sciences, an exception being the direction of art studies where the faculty mostly consists of males). Compared with the contemporary school where feminisation of the teacher's profession takes place (Kestere \& Kalke, 2014), the process of feminisation is not that explicit in this study regarding institutions of higher education: $53 \%$ of the respondents mention female university teachers, $28 \%$ mention male university teachers, and the remaining $19 \%$ say that the gender is not important.

Age. In Latvia, people become university teachers after taking their Master's or Doctoral degree, which means the age of 25 years or more. The respondents also show that the age of a typical university teacher is between 40 and 70 years, and one student has mentioned that the age is above 30 years. University teachers must have certain life and research experience (henceforward, text in italics reflects quotations from the questionnaires), they are wisepeople who are able to present themselves well in various public premises. They are not elderly, but with a lot of experience. Thus, the age of the university teacher is not important for students. Instead, it is their competence and experience they can share.

Clothing, Footwear. The professional performance of a pedagogue and the outer image associated with it cannot be described unequivocally. To a certain extent, its formation will depend on the degree of education and the area the pedagogue works in, what courses they teach, and what teaching methods they use. For instance, the clothing of a university teacher giving lectures in social sciences will be different from that of a university teacher conducting laboratory work in natural sciences.

This idea is confirmed in the questionnaires filled in by the student teachers: a female university teacher usually thinks about the harmony of styles, colours, patterns, shapes, and also about comfort. They normally wear trousers or a skirt, a costume, dark, calm, ascetic colours (black, brown, grey), also white. The clothing has no bright colours. It is tasteful and stylish. The footwear mentioned includes boots or classic shoes on a low or high heel. The responses provided by the respondents can be divided into two groups. The majority think that female university teachers follow the clothing and footwear fashion trends, whereas others say that the clothing is old-fashioned, the appearance is insipid; the clothing could be more modern. A female respondent points to an interesting regularity which exists between the clothing and ethical conduct: The clothing mainly depends on the course they teach. Typically they dress conservatively, but it is more pleasant and, therefore, the environment becomes more positive if the university teacher wears ,,non-restricting clothing”, with certain ethical standards being followed, of course.

The male university teacher is slightly stout, wears a suit, a tie which is typically mentioned as unusual, one that does not match the suit, the clothings has a European touch (functionality and quality over famous brands), clean and 
shiny leather footwear. A drawback mentioned is socks that do not match the rest (2 respondents). The only accessory is a watch.

Accessories and Jewellery. The students have paid more attention to the accessories and jewellery. A male respondent has linked the reality and the preference in his response by indicating that the university teacher's accessories highlight the clothing or the nature of the university teacher, something that shows the personality would be preferable. The accessory mentioned in association with male university teachers is a briefcase containing a lot of documents, whereas for female university teachers it is a rather large handbag which holds its shape. Spectacles have been mentioned 7 times. The most frequently mentioned accessories include tablet computers, quality pens (which also get lost), whiteboard pens, a planner with the university emblem, a mobile phone which is not displayed openly. There are differences with regard to the jewellery the respondents notice: 12 respondents think they are inconspicuous, small, 32 respondents emphasise that the jewellery (brooches, necklaces, earrings, beads, bracelets, rings) are carefully selected, quality (it is not imitation jewellery, gold jewellery). 3 respondents mention scarves that not only complement the attire, but also help keep warm.

Hair.Female university teachers wear predominantly short hair, the hair is always clean and neat (11 respondents).

Voice.As seen by the students, the voice tone of the university teachers is individual, but loud (loud enough to shout louder than disobedient students), sonorous, confident voices tend to prevail. The voice is the most important. It should not be monotonous. It is typicallyclear, with varying tonality. The university teacher is able to change the intonation to maintain the attention of the audience. The voice tone is addressing, pleasant, and the speech is clear. Always speaks confidently, freely, naturally, calmly. Still always slightly tired voice. If the voice is silent, the students think that this suggests lack of any interest. A monotonous voice tone, which suggests dullness, is specifically mentioned in association with male university teachers. The university faculty have a rich vocabulary, but a large part of it is complicated and not understandable to the student. The speech is mostly a monologue which is tiresome for students and prevents them from active involvement.

Facial Expressions and Gestures. Only a few respondents have mentioned gestures and facial expressions, by saying it is adequate. The facial expressions of the university teacher are pleasant, comes into the auditorium with a smile, gestures with both arms, but not over-excessively. 1 respondent indicates that the gestures are emotional and there is too many of them. Smiling is more often mentioned in association with female university teachers (12 respondents).

Manners and Behaviour. The analysis of the students' questionnaires shows that many have described not only the behaviour and manners of the university faculty in them, but also their character traits. It is specified that the 
teachers in the Faculty of Education, Psychology and Art are very responsive, understanding, helping, open, communicable. It is always possible to talk with them, they are cooperation-centred, able to captivate and inspire students. Mostly, many university teachers like their job and come to their students with joy, but still 30\% of them work just "for a tick", and their lectures are boring. The personal properties and character traits mentioned by many respondents include tolerance, understanding, experience. Sense of humour has been mentioned in the responses of 9 respondents.

Male university teachers are silent and even-tempered; they do not go too much into detail. Female university teachers are more open, demanding, and even-tempered. University teachers give assignments that require working independently, and they like discussion. The plan of the lecture is sometimes not followed, i.e., the female university teacher gets carried away so much in her speech that no one remembers or understands any more how she came to this. 1 respondent feels awe, respect, sometimes concern, and even fear when meeting a member of the university faculty. Speaking about the competence of the university teachers, students think that the university teachers are knowledgeable in their areas, are able to debate convincingly and consider various different points of view (very good at expressing themselves about various points of view in a intelligent manner), have sufficient command of the new information technologies. The evaluations are based on criteria instead of assessment of the individual abilities. The sessions often follow the same pattern (either a PowerPoint presentation or oral explanation).

The location in the room has not been described by any respondent, and the drawings also show the university faculty in an ,empty space”. 1 respondent has added that female university teachers stand and thus demonstrate their respect towards their students, and another respondent has mentioned that it is important for the university teacher to move around the room and address the students individually, and it is essential that they spend time just to have a friendly chat with the students. Such a sign might suggest a specific feature in the audience of student teachers, i.e., explicit need for contact.

In 7 questionnaires, the students have used the debitive mood, and this suggests that they describe a typical university teacher instead of an ideal one.

\section{Conclusions}

The model is the most influential tool of education in pedagogics. The university faculty play a significant role in the training of the future students and in the process of their becoming teachers. Students perceive the values, points of view, preferences, manner of behaviour, and even the outer appearance of the university faculty, and this may have impacts on the professional performance of student teachers later on in their career. 
The importance of the image of the university teacher and their being a model can be seen in the statements provided by the student teachers in their questionnaires, such as they [university teachers] are in front of an audience and deliver their message. A university teacher is a responsible individual, as they are responsible for what their students will become after the lectures. I can now take many things over from the university teacher and use them in my own future.

It was revealed in the study that the university faculty in teacher education according to the students of the Faculty of Education, Psychology and Art of the University of Latvia consists of females (53\% of the responses) or males $(28 \%$ of the responses) between 40 and 70 years of age.

What could student teachers learn from the university faculty then? They are always dressed smartly and tastefully, with matching clothing items, wear leather shoes or boots (females).

The mentioned accessories include spectacles, tablet computers, pens, bags of various types. Female university teachers wear quality, interesting, inconspicuous jewellery. The voice is loud, convincing, sonorous. The facial features and gestures are adequate, sometimes over-emotional.

The personal properties and the character traits of the university teachers are important. Responsiveness, helpfulness, respect towards the student, sense of humour, pedagogical competence are the positive features the student teachers might potentially use later on in their professional careers. One can conclude that student teachers find it important for the outer expressions of the university teacher to match their personality (values, attitudes, and actions), so that the university teacher not only teaches how to teach, but also uses their own example to demonstrate these ideals to their students during the sessions.

Of course, negative manifestations can be seen in the image of the university faculty as well, such as lack of interest, inability to plan, excessive use of foreign words in their speech, ignoring of the individual achievements in the assessment.

Studying the image of the university faculty is one of the tools for the evaluation of the quality of the studies in the institution of higher education which includes both aesthetic and ethical aspects of the professionalism of the university teacher. Its results help the university faculty understand how they are perceived by the students, what the students pay attention to in the outer appearance of the teacher, and what they evaluate in the performance of the university teacher. Consequently, this knowledge may be useful for the university teachers themselves in their self-improvement based on better awareness of the influences of their personalities and performance on the students.

One of the directions for further research is comparison of the image of the university faculty between various sectors, the influences thereof on the motivation of the future specialists for professional performance. 


\section{References}

Böss-Ostendorf, A., Senft, H. (2010). Einführung in die Hochschul-Lehre.Ein DidaktikCoach. Opladen \& Farmington Hills: Verlag Barbara Budrich.

Enders, J., Teichler, U. (1995). Der Hochschullehrerberuf im internationalen Vergleich. Ergebnisse einer Befragung über die wissenschaftliche Profession in 13 Ländern. Bonn: Bundesministerium für Bildung, Wissenschaft, Forschung und Technologie.

Kalı̧ke, B., Ķestere, I. (2010). Skolotāja vizuālais tēls padomju periodā un mūsdienās: skolēnu viedoklis. No: Krūze, A., Ķestere, I. (Sast.) Pedagogijas vēsture: 15 jautājumi (261. 273. lpp.). Rīga: RaKa.

Knoll, J. (1998). Hochschuldidaktik der Erwachsenenbildung. In: Knoll, J. (Hg.) Theorie und Praxis der Erwachsenenbildung (S. 13 - 47). Bad Heilbrunn: Klinkhardt.

Ķestere I., Kalı̧e B. (2014). Latvijas skolotāju vizuālais tēls Eiropas skolēnu perspektīvā. Latvijas Zinātñu Akadèmijas Vēstis, 1/2, 55 - 68.

Ķestere, I. (2007). Lietišşā etiķete. Eiropas pieredze. Rīga: Zvaigzne ABC.

Ķestere, I. (2005). Pedagogijas vēsture. Skola, skolotājs, skolēns. Rīga: Zvaigzne ABC.

Lejniece, Z. (2005). Ėtika pedagoga darbā. Rīga: RTU Izdevniecība.

Nóvoa A. (2000). Ways of saying, ways of seeing: public images of teachers (19th -20 th Centuries). Paedagogica Historica. 36 (1), 21-52.

Reitzer, Ch. (2014). Erfolgreich lehren: Ermutigen, motivieren, begeistern. Berlin, Heidelberg: Springer Verlag.

Skujiņa, V. et al. (2000). Pedagog̣ijas terminu skaidrojošā vārdnīca. Rīga: Zvaigzne ABC.

Swennen, A., van der Klink, M. (Eds.) (2009). Becoming a Teacher Educator: Theory and Practice for Teacher Educators. The Netherlands: Springer.

Špona, A. (2004). Audzināšanas process teorijā un praksē. Rīga: RaKa.

Vandermeersch, P. A. (1996). Die Universitätslehrer. In: Rüegg, W. (Hg.) Geschichte der Universität in Europa. Band II: Von der Reformation zur Französischen Revolution (1500-1800) (S.181-212). München: Verlag C.H. Beck.

Verger, J. (1993). Die Universitätslehrer. In: Rüegg, W. (Hg.) Geschichte der Universität in Europa. Band I: Mittelalter (S.147 - 157). München: Verlag C.H. Beck.

Vick, M. (2000). What does a teacher look like?Paedagogica Historica, 36 (1), 247-263.

Weber, S., Mitchell, C. (1995).That's Funny, You Don't Look Like A Teacher! London, Washington: The Falmer Press. 